\title{
Insulin, dexamethasone and their interactions in the control of glucose metabolism in adipose tissue from lactating and non- lactating sheep
}

\author{
Richard G. VERNON and Eleanor TAYLOR \\ Hannah Research Institute, Ayr, Scotland KA6 5HL, U.K.
}

\begin{abstract}
1. Lactation results in decreased glucose and acetate utilization and increased lactate output by sheep adipose tissue. 2. The ability of insulin to stimulate acetate uptake was lost in adipose tissue from lactating sheep, whereas both the response and the sensitivity $\left(\mathrm{ED}_{50}\right)$ for insulin for stimulation of glucose conversion into products other than lactate were decreased. These impairments were partly restored by prolonged incubation of adipose tissue for $48 \mathrm{~h}$. 3. The ability of insulin to stimulate lactate output was not altered by lactation. 4. Dexamethasone inhibited glucose uptake, lactate output and glycerol output in adipose tissue from both non-lactating and lactating sheep, with an $\mathrm{ED}_{50}$ of about $1 \mathrm{nM}$. Dexamethasone inhibited acetate uptake by adipose tissue from non-lactating sheep, but this effect was not observed with adipose tissue from lactating sheep. 5. Dexamethasone inhibited the stimulation of glucose uptake at all concentrations of insulin used; the effect varied with insulin concentration and resulted in an accentuation of the insulin dose-response curve. The insulin dose-response curve in the presence of dexamethasone was muted during lactation. 6 . The overall effect of these adaptations is to ensure that glucose and acetate utilization by adipose tissue after an insulin surge is diminished during lactation.
\end{abstract}

\section{INTRODUCTION}

Glucose metabolism in sheep and other ruminant animals differs from that of the rat in several important respects. Unlike the rat, sheep absorb very little glucose, as almost all dietary carbohydrate is converted into short-chain fatty acids in the rumen, so most of the glucose used by sheep is produced by gluconeogenesis (see Ballard et al., 1969). The need for glucose production is minimized in sheep by increased utilization of acetate for oxidative purposes (see Bell, 1980) and as a precursor for fatty acid synthesis (see Vernon \& Flint, 1983).

Although acetate is the major source of carbon for fatty acid synthesis in adipose tissue in sheep, the tissue also uses some glucose to produce NADPH by oxidation via the pentose phosphate cycle, whereas glucose is the only significant precursor for acylglycerol glycerol synthesis (see Vernon, 1980), and there is some glucose oxidation via the tricarboxylic acid cycle (Robertson et al., 1982). In addition, a substantial proportion of glucose taken up by the tissue is released as lactate both in vivo (Khachadurian et al., 1966) and in vitro (Robertson et al., 1982).

The regulation of glucose metabolism in sheep adipose tissue is not fully resolved. Insulin stimulates, whereas glucocorticoids inhibit, glucose utilization (Vernon, 1979; Plested et al., 1987a), as in the rat adipose tissue, but the mechanisms may differ. The major site of action of glucocorticoids in rat adipose tissue appears to be

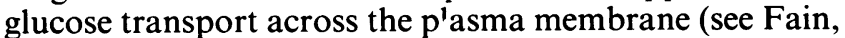
1979), whereas in sheep adipose tissue the major site(s) of inhibition by glucocorticoids appear to be distal to glucose transport (Plested et al., 1987a). Also, unlike rat adipose tissue, insulin has little or no effect on adiposetissue metabolism in sheep during incubations of $2-3 \mathrm{~h}$ (see Vernon, 1980), but does stimulate both fatty acid synthesis and glucose utilization when incubations are prolonged for $24 \mathrm{~h}$ or more (Vernon, 1979, 1982; Plested et al., 1987a).

Synthesis of lactose in the mammary gland doubles the glucose requirement of lactating sheep (Bergman \& Hogue, 1967). As a result gluconeogenesis is increased in the liver, but in addition glucose utilization in vivo by the rest of the body (apart from the mammary gland) is decreased (Bergman \& Hogue, 1967). Glucose oxidation (Smith \& Walsh, 1984) and acylglycerol glycerol synthesis from glucose (Vernon et al., 1981) are decreased in adipose tissue from lactating sheep. The objective of the present study was to ascertain if changes in glucose metabolism in adipose tissue of lactating sheep are associated with changes in the response or sensitivity of the tissue to insulin and glucocorticoids.

\section{EXPERIMENTAL}

\section{Animals}

Sheep were 4- or 5-year old multiparous Finn $\times$ DorsetHorn cross-bred ewes. They were fed on hay plus a cereal mix as described previously (Vernon et al., 1981). Lactating sheep were suckling either two or three lambs and were sampled at about 18 days of lactation. For all sheep, a jugular catheter was inserted $24 \mathrm{~h}$ before animals were killed; on the day of slaughter, animals were anaesthetized at 10:00 h (Vernon et al., 1981) and exsanguinated, after which samples of subcutaneous adipose tissue were removed asceptically from the flank immediately posterior to a hind-limb and placed in sterile $0.15 \mathrm{M}-\mathrm{NaCl}$ at $37^{\circ} \mathrm{C}$.

\section{Tissue culture}

Pieces of adipose tissue weighing 5-10 mg were prepared and maintained in tissue culture in Medium 199 containing Earle's salts, L-glutamine, Hepes (Gibco- 
Table 1. Effects of lactation and insulin on glucose removal from the culture medium by pieces of sheep adipose tissue

Adipose-tissue pieces from non-lactating (Non-lact.) and from lactating (Lact.) sheep were incubated in supplemented Medium 199 (see the text) for $24 \mathrm{~h}$ or $48 \mathrm{~h}$ in the presence of various concentrations of insulin, and the amount of glucose removed from the medium was determined. Results are expressed per $10^{6}$ cell units (see the text) and are presented for two independent experiments, each undertaken in a different year. All results are means of five values and six values in Expts. I and II respectively. $\operatorname{SED}_{1}$ and $\mathrm{SED}_{2}$ (defined in the text) were 1.25 and 1.50 respectively in Expt. I and 1.34 and 2.53 respectively in Expt. II. Values in a row with a different superscript $(\mathrm{a}, \mathrm{b}, \mathrm{c}, \mathrm{d})$ differ significantly $(P<0.05)$.

\begin{tabular}{|c|c|c|c|c|c|c|c|c|c|c|c|c|}
\hline \multirow[b]{2}{*}{ Expt. } & \multirow[b]{2}{*}{ State } & \multirow[b]{2}{*}{ Time } & \multirow{2}{*}{$\begin{array}{l}\text { Insulin } \\
(\mathrm{nM}) \ldots\end{array}$} & \multicolumn{9}{|c|}{ Glucose utilization ( $\mu \mathrm{mol} / 10^{6}$ cell units per 24 or $48 \mathrm{~h}$ ) } \\
\hline & & & & 0.0 & 0.02 & 0.05 & 0.08 & 0.17 & 0.33 & 0.83 & 1.7 & 17 \\
\hline \multirow[t]{4}{*}{ I } & Non-lact. & $24 \mathrm{~h}$ & & $6.9^{\mathrm{a}}$ & - & - & $9.8^{\mathrm{b}}$ & $10.3^{b}$ & $10.7^{\mathrm{b}}$ & $11.2^{\mathrm{b}}$ & $11.2^{\mathrm{b}}$ & $11.4^{\mathrm{b}}$ \\
\hline & Lact. & $24 \mathrm{~h}$ & & $4.0^{\mathrm{a}}$ & - & - & $5.3^{\mathrm{a}}$ & $7.9^{\mathrm{b}}$ & $6.4^{\mathrm{a}}$ & $7.5^{\mathrm{b}}$ & $7.9^{\mathrm{b}}$ & $8.0^{\mathrm{b}}$ \\
\hline & Non-lact. & $48 \mathrm{~h}$ & & $14.3^{\mathrm{a}}$ & - & - & $20.0^{\mathrm{b}}$ & $21.0^{\mathrm{b}}$ & $22.2^{\mathrm{bc}}$ & $23.9^{\mathrm{cd}}$ & $25.3^{\text {de }}$ & $27.2^{\mathrm{e}}$ \\
\hline & Lact. & $48 \mathrm{~h}$ & & $7.3^{\mathrm{a}}$ & - & - & $9.8^{\mathrm{a}}$ & $14.7^{\mathrm{b}}$ & $14.9^{b}$ & $15.4^{b}$ & $19.3^{c}$ & $18.3^{\mathrm{c}}$ \\
\hline \multirow[t]{2}{*}{ II } & Non-lact. & $24 \mathrm{~h}$ & & $7.2^{\mathrm{a}}$ & $8.4^{\mathrm{a}}$ & $9.1^{\mathrm{a}}$ & - & $12.7^{\mathrm{b}}$ & - & - & $14.4^{\mathrm{b}}$ & $14.4^{b}$ \\
\hline & Lact. & $24 \mathrm{~h}$ & & $6.4^{\mathrm{a}}$ & $7.6^{\mathrm{a}}$ & $5.5^{\mathrm{a}}$ & - & $7.1^{\mathrm{a}}$ & - & - & $8.5^{\mathrm{a}}$ & $9.7^{b}$ \\
\hline
\end{tabular}

Biocult, Paisley, U.K.), 2 mM-acetate and antibiotics with a gas phase of air $/ \mathrm{CO}_{2}(19: 1)$ as described previously (Robertson et al., 1982). Bovine insulin and dexamethasone (Sigma Chemical Co.) were added as described in the text and legends. After 24 or $48 \mathrm{~h}$ of culture, the adipose-tissue pieces were blotted dry and frozen in liquid $\mathrm{N}_{2}$ before determination of pyruvate kinase activity (Robertson et al., 1982), and samples of culture media were taken and stored at $-20^{\circ} \mathrm{C}$ for assay of glucose, lactate, acetate, glycerol and insulin (Vernon et al., 1981).

\section{Other assays}

The mean cell volume of adipocytes and their number per $\mathrm{g}$ of adipose-tissue pieces before culture were determined as described previously (Robertson et al., 1982); the DNA concentration of tissue pieces before culture was determined by the method of Labarca \& Paigen (1980). The binding of ${ }^{125}$ I-insulin to adipocytes was measured as described by Vernon et al. (1981).

\section{Statistical analysis}

Results quoted in the text are means \pm S.E.M. and were compared by Student's $t$ test. Results given in Tables and Figures were analysed by analysis of variance. This yielded two SED values (standard error of difference between means) denoted by $\mathrm{SED}_{1}$ and $\mathrm{SED}_{2}$. $\mathrm{SED}_{1}$ pertains to values for animals in the same physiological state, and $\mathrm{SED}_{2}$ is for comparing values between non-lactating and lactating sheep. In addition to analyses of untransformed results, analysis of variance was also performed with log-transformed results. In general, analyses of logtransformed results gave higher variance ratios and smaller coefficients of variation than did corresponding analyses of untransformed data. However, both analyses led to essentially the same conclusions, and so mean values and SED values quoted pertain to untransformed data; noteworthy differences are mentioned in the text.

\section{RESULTS}

Results are given for two separate experiments (denoted as Expt. I and II), which were performed in different years. The first study focused on glucose metabolism and insulin action over 24 and $48 \mathrm{~h}$ of tissue culture, whereas the effect of both insulin and the glucocorticoid analogue dexamethasone on a wider variety of variables was examined in the second study.

\section{Characterization of the adipose tissue}

In Expt. I the adipocyte mean cell volume was $690 \pm 42 \mathrm{pl}$ and $571 \pm 110 \mathrm{pl}$ (respectively) for nonlactating and lactating sheep, and the numbers of adipocytes/g of tissue were $1.28( \pm 0.07) \times 10^{6}$ and $1.70( \pm 0.29) \times 10^{6}$ respectively for non-lactating and lactating sheep (all values are means \pm S.E.M. for five observations). Very similar values were obtained in Expt. II: adipocyte mean cell volumes were $777 \pm 156 \mathrm{pl}$ and $555 \pm 31 \mathrm{pl}$ for non-lactating and lactating sheep; numbers of adipocytes per $\mathrm{g}$ tissue were $1.35( \pm 0.2) \times 10^{6}$ and $1.65( \pm 0.1) \times 10^{6}$; DNA content of the tissue was $63.7 \pm 9.1$ and $71.5 \pm 2.9 \mu \mathrm{g} / \mathrm{g}$ (all values are means \pm S.E.M. for six observations, and the first value of each pair is for non-lactating and the second for lactating

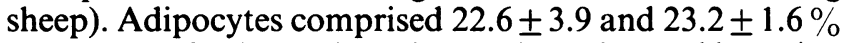
of the cells of adipose tissue in non-lactating and lactating sheep respectively (calculated from the number of adipocytes and the DNA content of the tissue). Although adipocytes comprise less than $25 \%$ of the cells of the tissue, they probably account for over half the metabolic activity of the tissue (see Vernon et al., 1987), hence expression of metabolic data either per adipocyte or per $\mu \mathrm{g}$ of DNA is not wholly appropriate. As the proportion of adipocytes did not change with lactation, metabolic activities are expressed per $10^{6}$ cell units, which is the activity per $\mathrm{g}$ of tissue divided by number of adipocytes $\left(\times 10^{-6}\right)$ per $g$ of tissue; this basis represents the activity of $10^{6}$ adipocytes and their contingent of non-adipocytes.

\section{Response to insulin}

Incubation of adipose tissue from non-lactating sheep in the presence of various concentrations of insulin for $24 \mathrm{~h}$ or $48 \mathrm{~h}$ confirmed that glucose uptake was essentially linear with respect to time and that it was stimulated by insulin (Table 1). The concentration of insulin required to achieve half-maximum stimulation was about $0.05-0.08 \mathrm{~nm}$ over the first $24 \mathrm{~h}$ period and $0.13 \mathrm{~nm}$ over 


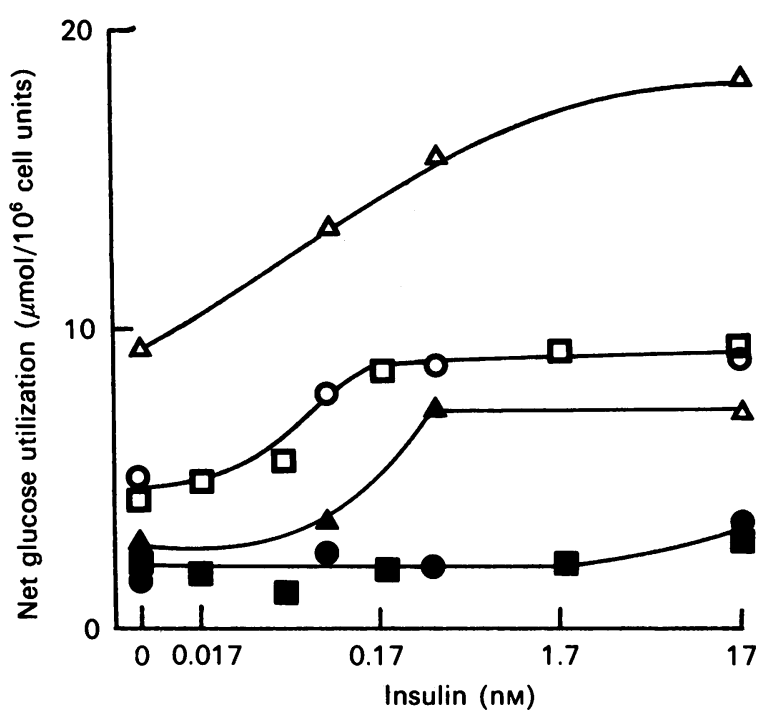

Fig. 1. Effect of lactation on insulin stimulation of net glucose utilization (conversion into products other than lactate) by adipose tissue from non-lactating and lactating sheep

Pieces of adipose tissue were maintained in supplemented Medium 199 for 24 or $48 \mathrm{~h}$ in the presence of various concentrations of insulin, and the amount of glucose removed from the medium and the amount of lactate released into the medium were determined. Results are expressed as $\mu \mathrm{mol}$ of glucose used $/ 10^{6}$ cell units (see the text) per 24 or $48 \mathrm{~h}$ as appropriate, and are means of five or six values. $\bigcirc, \square, \Delta$, Values for non-lactating sheep; $\boldsymbol{\top}, \boldsymbol{\Delta}, \boldsymbol{\Delta}$, values for lactating sheep; $\bigcirc, \boldsymbol{O}$, values for $24 \mathrm{~h}$, Expt. I; $\square, \square$, values for $24 \mathrm{~h}$, Expt. II ; $\Delta, \Delta$, values for $48 \mathrm{~h}$, Expt. I (see the text). Values were analysed by analysis of variance; there was a significant effect of lactation $(P<0.05)$ and of insulin $(P<0.002)$ and a significant interaction between insulin and lactation $(P<0.05)$ in both experiments. SED $_{1}$ values were $0.59,0.88$ and 1.26 for Expt. I $24 \mathrm{~h}$ and $48 \mathrm{~h}$ and Expt. II $24 \mathrm{~h}$ values respectively; $\mathrm{SED}_{2}$ values were $1.37,1.61$ and 2.42 for Expt. I $24 \mathrm{~h}$ and $48 \mathrm{~h}$ and Expt. II $24 \mathrm{~h}$ values respectively.
$48 \mathrm{~h}$. Insulin also stimulated glucose utilization by adipose tissue from lactating sheep, but glucose utilization was consistently lower in adipose tissue from such sheep, in the presence and absence of insulin, over both 24 and $48 \mathrm{~h}$ of incubation, than in adipose tissue from non-lactating sheep; this effect of lactation was highly significant in Expt. I (variance ratio 40.0, $P<0.001$ ). However, in Expt. II, although there was a very similar trend to that observed in Expt. I, the effect of lactation was not significant, owing to greater variability amongst sheep (cf. $\operatorname{SED}_{2}$, Table 1). The concentration of insulin required for half-maximum stimulation was greater with tissue from lactating sheep than from non-lactating sheep (about $0.13 \mathrm{nM}$ over $24 \mathrm{~h}$ in Expt. I, compared with $0.05 \mathrm{nM}$ ), and over $0.3 \mathrm{~nm}$ in Expt. II, compared with $0.08 \mathrm{nM}$ for tissue from nonlactating sheep. The loss of insulin from the incubation medium, assessed by radioimmunoassay, was the same with tissue from non-lactating and lactating sheep. When the initial concentration was $10 \mathrm{ng} / \mathrm{ml} .84 \pm 7$ and $69 \pm 11 \%$ respectively remained after 24 and $48 \mathrm{~h}$ of incubation with adipose tissue from non-lactating sheep, and $70 \pm 12$ and $62 \pm 2 \%$ remained after 24 and $48 \mathrm{~h}$ respectively with tissue from lactating sheep.

Lactate output in the two experiments amounted to 20 and $43 \%$ of glucose uptake for tissue from non-lactating sheep, and 55 and $67 \%$ of glucose uptake with tissue from lactating sheep. When glucose uptake was adjusted for lactate output (net glucose utilization), any differences in rates of glucose utilization observed in the two experiments were eliminated (Fig. 1). Insulin stimulated net glucose utilization $(P<0.001$, both experiments) in tissue from non-lactating sheep $\left(\mathrm{ED}_{50}\right.$ about $0.07 \mathrm{nM}$; Fig. 1), but insulin had little or no effect with tissue from lactating sheep $\left(\mathrm{ED}_{50}>1.7 \mathrm{nM}\right.$; Fig. 1). Continuing the incubation for $48 \mathrm{~h}$, however, partly restored the responsiveness of tissue from lactating sheep to insulin, with an $\mathrm{ED}_{50}$ for insulin of about $0.17 \mathrm{nM}$.

Insulin stimulated lactate production in adipose tissue from both lactating and non-lactating sheep $(P<0.001$; Table 2); the $\mathrm{ED}_{50}$ was about $0.17 \mathrm{nM}$-insulin in both

Table 2. Effects of insulin and lactation on lactate and glycerol output, acetate uptake and the pyruvate kinase activity of pieces of sheep adipose tissue during tissue culture for $48 \mathrm{~h}$

Adipose-tissue pieces from non-lactating (Non-lact.) and lactating (Lact.) sheep were incubated in supplemented Medium 199 (see the text) for $48 \mathrm{~h}$. The amount of acetate removed from the culture medium and the amounts of lactate and glycerol released into the culture medium were determined, and the pyruvate kinase activity of the tissue pieces was measured. Results are expressed as $\mu \mathrm{mol}$ released or removed $/ 24 \mathrm{~h}$ per $10^{6}$ cell units (see the text), or as $\mu \mathrm{mol} / \mathrm{min}$ per $10^{6}$ cell units for pyruvate kinase. Results are for sheep of Expt. II (see the text) and are means of six observations in each case. SED and SED $_{2}$ are defined in the text (statistical analysis). Values in a column with a different subscript $(\mathrm{a}, \mathrm{b}, \mathrm{c}, \mathrm{d})$ differ significantly $(P<0.05)$. Values for lactating sheep marked with an asterisk $\left({ }^{*}\right)$ differ from the corresponding mean value for non-lactating sheep $(P<0.05)$.

\begin{tabular}{|c|c|c|c|c|c|c|c|c|c|}
\hline \multirow{2}{*}{$\begin{array}{l}\text { Insulin in } \\
\text { culture } \\
\text { medium (nM) }\end{array}$} & \multirow[b]{2}{*}{ State... } & \multicolumn{2}{|c|}{ Lactate output } & \multicolumn{2}{|c|}{ Acetate uptake } & \multicolumn{2}{|c|}{ Glycerol output } & \multicolumn{2}{|c|}{ Pyruvate kinase } \\
\hline & & Non-lact. & Lact. & Non-lact. & Lact. & Non-lact. & Lact. & Non-lact. & Lact. \\
\hline $\begin{array}{l}0 \\
0.02 \\
0.05 \\
0.17 \\
1.7 \\
17\end{array}$ & & $\begin{array}{l}6.3^{\mathrm{a}} \\
7.1^{\mathrm{a}} \\
6.9^{\mathrm{a}} \\
8.2^{\mathrm{ab}} \\
9.6^{\mathrm{b}} \\
9.8^{\mathrm{b}}\end{array}$ & $\begin{array}{c}8.7^{\mathrm{a}} \\
10.8^{\mathrm{ab}} \\
8.2^{\mathrm{a}} \\
11.2^{\mathrm{b}} \\
13.0^{\mathrm{b}} \\
13.3^{\mathrm{b}}\end{array}$ & $\begin{array}{c}9.7^{\mathrm{a}} \\
14.8^{\mathrm{b}} \\
15.8^{\mathrm{bc}} \\
19.0^{\mathrm{cd}} \\
21.6^{\mathrm{d}} \\
20.2^{\mathrm{d}}\end{array}$ & $\begin{array}{l}2.0^{a *} \\
2.8^{a *} \\
2.1^{a *} \\
2.9^{a *} \\
3.4^{a *} \\
2.9^{a *}\end{array}$ & $\begin{array}{l}1.49^{\mathrm{a}} \\
1.39^{\mathrm{a}} \\
1.30^{\mathrm{ab}} \\
1.16^{\mathrm{bc}} \\
1.03^{\mathrm{c}} \\
1.07^{\mathrm{c}}\end{array}$ & $\begin{array}{l}0.65^{\mathrm{a} *} \\
0.72^{\mathrm{a} *} \\
0.59^{\mathrm{a} *} \\
0.57^{\mathrm{a}} \\
0.56^{\mathrm{a}} \\
0.56^{\mathrm{a}}\end{array}$ & $\begin{array}{l}0.65^{\mathrm{a}} \\
0.82^{\mathrm{ab}} \\
0.18^{\mathrm{ab}} \\
0.99^{\mathrm{bc}} \\
1.14^{\mathrm{c}} \\
1.14^{\mathrm{c}}\end{array}$ & $\begin{array}{l}0.56^{\mathrm{a}} \\
0.62^{\mathrm{ab}} \\
0.61^{\mathrm{ab}} \\
0.61^{\mathrm{ab}} \\
0.17^{\mathrm{ab} *} \\
0.78^{\mathrm{b}}\end{array}$ \\
\hline $\begin{array}{l}\operatorname{SED}_{1} \\
\operatorname{SED}_{2}\end{array}$ & $\cdot:$ & 1.15 & $57^{1.15}$ & 1.84 & $9^{1.84}$ & 0.09 & $3^{0.09}$ & 0.09 & 0.09 \\
\hline
\end{tabular}


Table 3. Effect of dexamethasone and lactation on total glucose uptake, net glucose utilization (glucose uptake minus glucose released as lactate), lactate output, acetate uptake and glycerol output by pieces of sheep adipose tissue during tissue culture for $\mathbf{4 8}$ h

Results are expressed as $\mu \mathrm{mol}$ released or removed $/ 24 \mathrm{~h}$ per $10^{6}$ cell units (see the text) and are from Expt. II ; further details are given in the legends to Table 2 and Fig. 1.

\begin{tabular}{|c|c|c|c|c|c|c|c|c|c|c|c|}
\hline \multirow{2}{*}{$\begin{array}{l}\text { Dexamethasone } \\
\text { in culture } \\
\text { medium (nM) }\end{array}$} & \multirow[b]{2}{*}{ State... } & \multicolumn{2}{|c|}{ Glucose uptake } & \multicolumn{2}{|c|}{ Net glucose uptake } & \multicolumn{2}{|c|}{ Lactate output } & \multicolumn{2}{|c|}{ Acetate uptake } & \multicolumn{2}{|c|}{ Glycerol output } \\
\hline & & Non-lact. & Lact. & Non-lact. & Lact. & Non-lact. & Lact. & Non-lact. & Lact. & Non-lact. & Lact. \\
\hline 0 & & $7.20^{\mathrm{a}}$ & $6.45^{\mathrm{a}}$ & $4.06^{\mathrm{a}}$ & $2.13^{\mathrm{a} *}$ & $6.3^{\mathrm{ab}}$ & $8.7^{\mathrm{a}}$ & $9.7^{\mathrm{a}}$ & $2.0^{\mathrm{a} *}$ & $1.49^{\mathrm{a}}$ & $0.68^{\mathrm{ab}}$ \\
\hline 0.1 & & $7.10^{\mathrm{a}}$ & $6.29^{\mathrm{a}}$ & $3.51^{\mathrm{a}}$ & $1.48^{\mathrm{a} *}$ & $7.2^{\mathrm{b}}$ & $9.1^{\mathrm{a}}$ & $10.6^{a}$ & $1.7^{\mathrm{a*}}$ & $1.51^{\mathrm{a}}$ & $0.79^{b}$ \\
\hline 1 & & $3.80^{\mathrm{b}}$ & $4.62^{\mathrm{ab}}$ & $1.83^{\mathrm{b}}$ & $1.73^{\mathrm{a}}$ & $4.0^{\mathrm{ac}}$ & $6.0^{b}$ & $6.9^{\mathrm{b}}$ & $1.7^{a *}$ & $0.87^{\mathrm{b}}$ & $0.49^{a c}$ \\
\hline 10 & & $2.07^{\mathrm{b}}$ & $3.07^{\mathrm{b}}$ & $1.16^{\mathrm{b}}$ & $1.13^{\mathrm{a}}$ & $1.8^{\mathrm{c}}$ & $4.0^{b}$ & $5.9^{b}$ & $1.5^{\mathrm{a} *}$ & $0.73^{b}$ & $0.37^{\mathrm{c}}$ \\
\hline 100 & & $2.62^{\mathrm{b}}$ & $3.75^{\mathrm{b}}$ & $1.33^{\mathrm{b}}$ & $1.12^{\mathrm{a}}$ & $2.7^{\mathrm{c}}$ & $5.3^{\mathrm{b}}$ & $7.4^{\mathrm{ab}}$ & $1.8^{\mathrm{a} *}$ & $0.86^{\mathrm{b}}$ & $0.39^{a c}$ \\
\hline $\mathrm{SED}_{1}$ & & 0.93 & 0.93 & 0.57 & 0.57 & 1.16 & 1.16 & 1.20 & 1.20 & 0.15 & 0.15 \\
\hline $\mathrm{SED}_{2}$ & & \multicolumn{2}{|c|}{1.26} & \multicolumn{2}{|c|}{0.78} & \multicolumn{2}{|c|}{1.89} & \multicolumn{2}{|c|}{2.42} & \multicolumn{2}{|c|}{0.32} \\
\hline
\end{tabular}

states. Lactation increased lactate output $(P<0.01)$ in Expt. I (results not shown), but, although a similar trend was evident in Expt. II (Table 2), the difference was not statistically significant. Acetate uptake was increased by insulin $(P<0.001)$ in adipose tissue from non-lactating sheep, with an $\mathrm{ED}_{50}$ of about $0.08 \mathrm{~nm}$ (Table 2). Acetate uptake was much lower $(P<0.001)$ in adipose tissue from lactating sheep, and was not increased by the addition of insulin (Table 2). Insulin also had no effect on glycerol release from adipose tissue of lactating sheep, but inhibited release $(P<0.01)$ from adipose tissue of non-lactating sheep $\left(\mathrm{ED}_{50} 0.08 \mathrm{nM}\right.$; Table 2).

Pyruvate kinase activity was increased by $75 \%$ in adipose tissue from non-lactating sheep when incubated for $24 \mathrm{~h}$ in the presence of insulin; $\mathrm{ED}_{50}$ was about $0.17 \mathrm{~nm}$ (Table 2). The pyruvate kinase activity of adipose tissue from lactating sheep was the same as that of nonlactating sheep after incubation for $24 \mathrm{~h}$ in the absence of insulin (Table 2). However, incubation for $24 \mathrm{~h}$ in the presence of insulin resulted in a smaller (39\%) increase in activity, and the $\mathrm{ED}_{50}$ for insulin was about $1.7 \mathrm{nM}$ (Table 2).

\section{Insulin binding}

Scatchard plots of insulin binding to adipocytes from lactating and non-lactating sheep did not differ (results not shown). The total number of receptors per adipocyte were $2.6( \pm 0.6) \times 10^{5}$ and $1.9( \pm 0.4) \times 10^{5}$ for nonlactating and lactating sheep respectively.

\section{Response to glucocorticoids}

The addition of dexamethasone to the culture media (in the absence of insulin) resulted in a significant decrease $(P<0.001$ in each case $)$ in total glucose uptake, lactate output, net glucose uptake and glycerol release (Table 3) in adipose tissue from both non-lactating and lactating sheep. A significant effect of dexamethasone on net glucose uptake by adipose tissue from lactating sheep was not apparent when untransformed values were analysed, but it was revealed when analysis of variance was performed on log-transformed results. Dexamethasone also inhibited acetate uptake $(P<0.01)$ in adipose tissue from non-lactating sheep, but not from lactating sheep (Table 3). Maximum effects were obtained with $10 \mathrm{nM}$-dexamethasone and half-maximum effects with about $1 \mathrm{~nm}$-dexamethasone for all variables studied.

Effects of dexamethasone were most marked on glucose metabolism (both total and net) and lactate release, which were inhibited by 72,69 and $71 \%$ respectively in adipose tissue from non-lactating sheep and by 52,53 and $54 \%$ respectively in adipose tissue from lactating sheep.

\section{Insulin-glucocorticoid interactions}

Inhibition of glucose uptake by dexamethasone was still apparent in the presence of insulin (Table 4), but the degree of inhibition was proportionately less $(10 \mathrm{nM}$ dexamethasone decreased glucose uptake by $71 \%$ in the absence of insulin, but by only $27 \%$ in the presence of $17 \mathrm{nM}$-insulin in adipose tissue from non-lactating sheep). However, maximum effects were still observed with $10 \mathrm{nM}$-dexamethasone, and the $\mathrm{ED}_{50}$ was again about $1 \mathrm{~nm}$ in the presence of insulin in adipose tissue from both lactating and non-lactating sheep.

The presence of dexamethasone at sub-maximally (1 nM) or maximally (10 nM) effective concentrations (Table 3) modified the dose-response curves for the stimulation of glucose uptake by insulin in adipose tissue from both non-lactating and lactating sheep (Table 4). The general effect of dexamethasone was to decrease the glucose uptake at any given concentration of insulin, thus displacing the insulin dose-response curves downwards. However, as noted above, the effects of dexamethasone were proportionately greater in the absence of insulin than in the presence of high concentrations of insulin, hence the overall effect of dexamethasone is to accentuate the insulin effect. Thus, in the absence of dexamethasone, the addition of $17 \mathrm{nM}$ insulin increased glucose uptake from 7.2 to $14.4 \mu \mathrm{mol} /$ $24 \mathrm{~h}$ per $10^{6}$ cell units (an increase of $100 \%$ ), whereas in the presence of $10 \mathrm{nM}$-dexamethasone addition of $17 \mathrm{nM}$ insulin increased uptake from 2.1 to $10.5 \mu \mathrm{mol} / 24 \mathrm{~h}$ per $10^{6}$ cell units (an increase of $400 \%$ ). The presence of dexamethasone had similar, but more muted, effects on glucose uptake by adipose tissue from lactating sheep (Table 4).

\section{DISCUSSION}

Lactation in sheep thus has a profound effect on the metabolism of adipose tissue and also on the response and sensitivity of the tissue to insulin. The decrease in utilization of acetate is probably due mainly to the decrease in the rate of fatty acid synthesis in the tissue 
Table 4. Effect of lactation on the interaction of insulin and dexamethasone on glucose removal from the culture medium by pieces of sheep adipose tissue

Pieces of adipose tissue from non-lactating and lactating sheep were incubated for $24 \mathrm{~h}$ in the presence and the absence of various concentrations of insulin and dexamethasone, after which the amount of glucose removed from the culture medium was determined. Results are from Expt. II, and further details are given in the legend to Table 2. SED Was 2.137 and SED $_{2}$ was 1.343 . Analysis of variance showed a significant effect of insulin (variance ratio $59.1, P<0.001$ ) and dexamethasone (variance ratio 27.6, $P<0.001$ ) and significant interactions between insulin and lactation (variance ratio $9.0, P<0.001$ ) (i.e. the effect of insulin was altered by lactation) and between dexamethasone and lactation (variance ratio 3.52, $P<0.05$ ). Analysis of log-transformed data confirmed these findings, and also showed a significant $(P<0.01)$ interaction between insulin and dexamethasone.

\begin{tabular}{|c|c|c|c|c|c|c|c|}
\hline \multirow{2}{*}{$\begin{array}{l}\text { Physiological } \\
\text { state }\end{array}$} & \multirow{2}{*}{$\begin{array}{c}\text { Dexamethasone } \\
\text { (nM) }\end{array}$} & \multirow{2}{*}{$\begin{array}{l}\text { Insulin } \\
\text { (nM)... }\end{array}$} & \multicolumn{5}{|c|}{ Glucose uptake ( $\mu \mathrm{mol} / 24 \mathrm{~h}$ per $10^{6}$ cell units) } \\
\hline & & & 0 & 0.05 & 0.17 & 1.7 & 17 \\
\hline \multirow{4}{*}{ Non-lactating } & 0 & & 7.2 & 9.1 & 12.6 & 14.3 & 14.4 \\
\hline & 1 & & 3.8 & 6.1 & 9.1 & 12.3 & 13.3 \\
\hline & 10 & & 2.1 & 5.3 & 5.8 & 10.6 & 10.5 \\
\hline & 100 & & 2.6 & 5.6 & 6.5 & 10.4 & 11.1 \\
\hline \multirow{4}{*}{ Lactating } & 0 & & 6.4 & 5.4 & 7.1 & 8.5 & 9.7 \\
\hline & 1 & & 4.6 & 5.6 & 6.4 & 8.5 & 8.3 \\
\hline & 10 & & 3.1 & 4.4 & 5.1 & 6.6 & 6.9 \\
\hline & 100 & & 3.7 & 4.0 & 5.0 & 7.3 & 7.0 \\
\hline
\end{tabular}

(Vernon et al., 1981; Smith \& Walsh, 1984); in addition there is a smaller decrease in acetate oxidation (Smith \& Walsh, 1984). The lower rate of glucose metabolism to products other than lactate during lactation is in accordance with the lower rate of acylglycerol glycerol synthesis from glucose (Vernon et al., 1981; Smith \& Walsh, 1984) and the lower rate of glucose oxidation to $\mathrm{CO}_{2}$ (Smith \& Walsh, 1984), the latter probably arising mainly from the diminished rate of fatty acid synthesis and hence need for glucose oxidation via the pentose phosphate pathway. The increase in lactate production during lactation may be due to a decrease in pyruvate dehydrogenase activity of the tissue (Vernon et al., 1987). The lactate released by adipose tissue in sheep is probably used for gluconeogenesis, which is increased during lactation (Bergman et al., 1974).

The most interesting finding of the present study is the diminished sensitivity $\left(\mathrm{ED}_{50}\right)$ of adipose tissue to insulin during lactation. The loss of sensitivity is selective, with the $\mathrm{ED}_{\mathbf{5 0}}$ for stimulation of net glucose utilization and also pyruvate kinase activity being markedly increased and the ability to modulate acetate uptake and glycerol release being lost altogether, whereas the ability of insulin to stimulate lactate production appears to be unaltered. Studies with isolated rat adipocytes have shown that stimulation of lactate production by insulin appears to be unaltered by lactation (Burnol et al., 1986). In addition, insulin ( $2.5 \mathrm{nM}$ ) increased glucose conversion into $\mathrm{CO}_{2}$ plus lipids by $160 \%$ in adipocytes from nonlactating rats, but by only $100 \%$ in adipocytes from lactating rats (Burnol et al., 1986). However, in contrast with the present study with sheep tissue, lactation did not alter the $E_{50}$ of insulin for stimulation of glucose conversion into $\mathrm{CO}_{2}$ plus lipid in rat adipocytes (Burnol et al., 1986) (production of $\mathrm{CO}_{2}$ and acylglycerol glycerol will account for most glucose used by sheep adipose tissue other than for the production of lactate; Robertson et al., 1982). In the rat the ability of insulin to stimulate fatty acid synthesis from glucose in adipocytes is decreased both in vivo (Burnol et al., 1983) and in vitro
(Burnol et al., 1986) during lactation, but it is not clear if there is a change in the $\mathrm{ED}_{50}$ for insulin.

Thus, in both rats and sheep, the ability of insulin to stimulate metabolic fluxes in adipose tissue is altered during lactation. In sheep, however, there is a decrease in sensitivity $\left(E D_{50}\right)$ as well as response, whereas in the rat there appears to be no change in sensitivity. In neither species is there any change in the number or affinity of the insulin receptors (Flint et al., 1979; the present work), suggesting that alterations are due to defects in the signal transduction subsequent to binding of the hormone to its receptor. Studies on the activation of pyruvate dehydrogenase in rats suggest that the ability to release a putative insulin second messenger from the adipocyte plasma membrane is lost during lactation (Kilgour \& Vernon, 1988). Release of a phosphooligosaccharide from the plasma membrane appears to be involved in the activation or inactivation of a variety of enzymes through phosphorylation or dephosphorylation by insulin (Saltiel, 1987; Alemany et al., 1987), but not of glucose transport by insulin (Kelly et al., 1987). Failure to release this second messenger in response to insulin, with a consequent failure to activate enzymes such as pyruvate dehydrogenase and acetylCoA carboxylase in adipose tissue of lactating sheep, would account for the observations in the present study. The increase in pyruvate kinase activity induced by insulin in sheep adipose tissue is prevented by actinomycin D (Plested et al., 1987a); hence lactation may also alter the ability of insulin to stimulate transcription. Intriguingly, whatever component of the insulin signal transduction is lost from sheep adipose tissue during lactation, it appears to be at least partly restored on incubation of the tissue in the presence of insulin for $48 \mathrm{~h}$ (Fig. 1).

Dose-response curves for the inhibition of glucose utilization by dexamethasone in sheep adipose tissue are similar to those reported previously for the inhibition of glucose oxidation (Roth \& Livingston, 1976) and glucose transport activity (Carter-Su \& Okamoto, 1985) 
in rat adipocytes, although the $\mathrm{ED}_{50}$ for dexamethasone $(0.7-1.0 \mathrm{nM})$ is slightly less than that for rat adipocytes (1-5 nM), and maximum effects were obtained with $10 \mathrm{nM}$ in the sheep rather than $100 \mathrm{~nm}$ in rat adipose tissue (Roth \& Livingston, 1976; Carter-Su \& Okamoto, 1985). Dexamethasone rather than cortisol was used in the present study, as the latter is metabolized by adipose tissue. However, a comparison of glucose inhibition by the two steroids showed that cortisol inhibited glucose utilization to the same extent as dexamethasone, but with an $\mathrm{ED}_{50}$ of 5-10 nM (results not shown). A similar response but lower affinity has been observed for cortisol compared with dexamethasone in 3T3-Ll adipocytes (Grunfeld et al., 1981). The concentration of free cortisol in sheep blood is in the range 5-10 nM (Sharpe et al., 1986), so changes in glucocorticoid concentration are likely to have effects on adipose-tissue metabolism in vivo.

Inhibition of lactate and glycerol release in sheep adipose tissue by dexamethasone is in accordance with a previous report (Plested et al., 1987a). The inhibition of acetate uptake by dexamethasone in adipose tissue from non-lactating sheep is at last partly due to inhibition of fatty acid synthesis (Etherton \& Evock, 1986; Plested et al., 1987b); the lack of such an effect in adipose tissue from lactating sheep is thus probably due to the very low rate of fatty acid synthesis in the tissue in this state (Vernon et al., 1981).

Sheep adipose tissue differs from rat adipose tissue (Yorke, 1967; Czech \& Fain, 1972) in that the effects of dexamethasone on glucose metabolism are still apparent in the presence of high concentrations of insulin and 5 mM-glucose (Plested et al., 1987a). An important effect of dexamethasone is to accentuate the insulin doseresponse curve for stimulation of glucose utilization in sheep adipose tissue, an effect which is markedly blunted by lactation. Lactation thus induces changes in the ability of sheep adipose tissue to respond to insulin, which will result in a decreased utilization of both glucose and also acetate by the tissue in response to an insulin surge (e.g. after a meal of cereals), thus facilitating the preferential utilization of these nutrients by other tissues, especially the mammary gland.

We thank Dr. D. J. Flint for measuring serum insulin concentrations and insulin binding to adipocytes, Mr. E. A. Hunter for advice and assistance with the statistical analysis, Miss S. Lindsay for analytical assistance, and Mr. C. E. Park and Mr. D. Fullarton for care of the animals.

\section{REFERENCES}

Alemany, S., Mato, J. M. \& Strälfors, P. (1987) Nature (London) 330, 77-79

Ballard, F. J., Hanson, R. W. \& Kronfeld, D. S. (1969) Fed. Proc. Fed. Am. Soc. Exp. Biol. 28, 218-231

Bell, A. W. (1980) Prog. Lipid Res. 18, 117-164

Bergman, E. N. \& Hogue, D. E. (1967) Am. J. Physiol. 213, 1378-1384

Bergman, E. N., Brockman, R. P. \& Kaufman, C. F. (1974) Fed. Proc. Fed. Am. Soc. Exp. Biol. 33, 1849-1854

Burnol, A. F., Leturque, A., Ferré, P. \& Girard, J. (1983) Am. J. Physiol. 245, E351-E358

Burnol, A. F., Guerre-Millo, M., Lavau, M. \& Girard, J. (1986) FEBS Lett. 194, 292-296

Carter-Su, C. \& Okamoto, K. (1985) Am. J. Physiol. 248, E215-E223

Czech, M. P. \& Fain, J. N. (1972) Endocrinology (Baltimore) 91, 518-522

Etherton, T. D. \& Evock, C. M. (1986) J. Anim. Sci. 62, $357-362$

Fain, J. N. (1979) in Glucocorticoid Hormone Action (Baxter, J. D. \& Rousseau, G. G., eds), pp. 547-560, Springer-Verlag, Berlin

Flint, D. J., Clegg, R. A., Sinnett-Smith, P. A. \& Vernon, R. G. (1979) Biochem. J. 182, 421-427

Grunfeld, C., Baird, K., Van Obberghen, E. \& Kahn, C. R. (1981) Endocrinology (Baltimore) 109, 1723-1730

Kelly, K. L., Mato, J. M., Merida, I. \& Jarett, L. (1987) Proc. Natl. Acad. Sci. U.S.A. 84, 6404-6407

Khachadurian, A. K., Adrouni, B. \& Yacoubian, H. (1966) J. Lipid Res. 7, 427-436

Kilgour, E. \& Vernon, R. G. (1988) Biochem. J. 252, 667-672

Labarca, C. \& Paigen, K. (1980) Anal. Biochem. 102, 344-352

Plested, C. P., Taylor, E., Brindley, D. N. \& Vernon, R. G. (1987a) Biochem. J. 247, 459-465

Plested, C. P., Finley, E., Brindley, D. N. \& Vernon, R. G. (1987b) Biochem. Soc. Trans. 15, 948

Robertson, J. P., Faulkner, A. \& Vernon, R. G. (1982) Biochem. J. 206, 577-586

Roth, G. S. \& Livingston, J. N, (1976) Endocrinology (Baltimore) 99, 831-839

Saltiel, A. R. (1987) Endocrinology (Baltimore) 120, 967-972

Sharpe, P. M., Buttery, P. J. \& Haynes, N. B. (1986) Br. J. Nutr. 56, 289-304

Smith, R. W. \& Walsh, A. (1984) Res. Vet. Sci 37, 320-323

Vernon, R. G. (1979) Int. J. Biochem. 10, 57-60

Vernon, R. G. (1980) Prog. Lipid Res. 19, 23-106

Vernon, R. G. (1982) Int. J. Biochem. 14, 255-258

Vernon, R. G. \& Flint, D. J. (1983) Proc. Nutr. Soc. 42, $315-331$

Vernon, R. G., Clegg, R. A. \& Flint, D. J. (1981) Biochem. J. 200, 307-314

Vernon, R. G., Faulkner, A., Finley, E., Pollock, H. \& Taylor, E. (1987) J. Anim. Sci. 64, 1395-1411

Yorke, R. E. (1967) J. Endocr. 39, 329-343 